\title{
Increasing the resolving power of determining the point gamma-radiation source direction in the precision method
}

\author{
A.N.Grigoryev ${ }^{1}$, Z.V.Bilyk ${ }^{1}$, Yu.V.Litvinov ${ }^{2}$, N.E.Polyansky ${ }^{2}$, \\ A.V.Sakun ${ }^{1}$, V.V.Marushchenko ${ }^{1}$, I.Yu.Cherniavskyi $^{1}$, \\ E.F.Voronkin ${ }^{3}$, S.Yu.Petrukhin ${ }^{1}$, S.V.Kasian ${ }^{1}$
}

${ }^{1}$ Faculty for Military Training, National Technical University "Kharkiv Polytechnic Institute", 192 Poltavskyi Shliakh Str., 61098 Kharkiv, Ukraine

${ }^{2}$ V.Karazin Kharkiv National University, 4 Svobody Sq., 61022 Kharkiv, Ukraine

${ }^{3}$ Institute for Single Crystals, STC "Institute for Single Crystals", National Academy of Sciences of Ukraine, 60 Nauky Ave., 61001 Kharkiv, Ukraine

\section{Received June 29, 2017}

Experiments have demonstrated the possibility of increasing the resolving power of determining the point gamma-radiation source direction in the precision method. The work involved reducing the step of the angle of rotation of an asymmetric absorber and shifting the detector relative to the maximum-minimum absorber thickness boundary. The ${ }^{137} \mathrm{Cs}$ gamma-radiation source direction was determined within the angles of the maximum and minimum thickness boundaries of the asymmetric absorber. The detector position was investigated for the maximum thickness of the asymmetric absorber on the boundary between the maximum and minimum thickness, and for the minimum thickness. The optimal position of the detector was found for the asymmetric absorber boundary, enabling to determine the maximum count rate in the gamma source direction. A specific position of the detector enables observing an increasing gamma radiation scattering over the copper-lead surface. The experiment used absorbers with spectrometric telluride-cadmium detectors. Information from the detectors was output to four multichannel gamma-radiation impulse analysers, which operated simultaneously in the spectrometer mode.

Keywords: precision method, determining the direction, detector behind an absorber, gamma-radiation source, asymmetric absorber, gamma-radiation scattering.

Экспериментально показана возможность увеличения точности определения положения точечного гамма-источника при измерении излучения. Исследовано влияние уменьшения шага угла поворота асимметрического поглотителя и смещения детектора относительно границы максимальной-минимальной толщины поглотителя на точность измерения, а также влияние размещения детектора за максимальной толщиной асимметрического поглотителя, внутри поглотителя и за его минимальной толщиной. Найдено оптимальное положение детектора, которое позволяет определить его максимальную скорость счета. Определенное положение детектора позволяет наблюдать увеличение рассеивания гамма-излучения при прохождении его вдоль медно-свинцовой поверхности. При проведении эксперимента использовались поглотители, в которых размещались спектрометрические теллурид-кадмиевые детекторы. Информация с детекторов выводилась на четыре многоканальных анализатора импульсов гамма-излучения, которые работали в спектрометрическом режиме одновременно. 
Збільшення точності визначення напрямку на точкове гамма-джерело у прецизійному методі та оптимальне розташування детектору в асиметричному поглиначі. О.М.Григор'єв, З.В.Білик, Ю.В.Литвинов, М.є.Полянський, О.В.Сакун, В.В.Марущенко, І.Ю.Чернявський, Є.Ф.Воронкін.

Експериментально показано можливість збільшення роздільної здатності визначення напрямку на точкове гамма-джерело у прецизійному методі. Робота полягає у зменшенні кроку кута повороту асиметричного поглинача та зміщенні детектора відносно межі максимальної-мінімальної товщини поглинача. Визначення напрямку на джерело гамма-випромінювання ${ }^{137} \mathrm{Cs}$ проводилося в околі кутів максимальної та мінімальної товщини асиметричного поглинача. Досліджено розташування детектора за максимальною товщиною асиметричного поглинача, на межі між максимальною та мінімальною товщиною, а також за мінімальною товщиною. Знайдено оптимальне положення детектору на межі асиметричного поглинача, що дозволяє визначати максимальну швидкість лічби у напрямку на гамма-джерело. Певне положення детектора дозволяє спостерігати збільшення розсіювання гамма-випромінювання при проходженні його вздовж мідно-свинцевої поверхні. При проведенні експерименту використовувалися поглиначі, в яких розташовувалися спектрометричні телурид кадмієві детектори. Інформація 3 детекторів виводилася на чотири багатоканальні аналізатори імпульсів гамма-випромінювання, що працювали у спектрометричному режимі одночасно.

\section{Introduction}

The authors have developed a precision method for determining the point gammasource direction [1]. For the method, a statistical direction error has been estimated, which is limited to several hundredths of a degree [2]. This value error was experimentally proved when determining the point gamma-source direction in a plane by using asymmetric absorbers (Fig. 1) [3]. Fig. 1 shows that the variation in the proportionality coefficient within the range of angles $359^{\circ}-1^{\circ}$ is the same as that for the range of angles $1^{\circ}-359^{\circ}$.

The practical implementation of the precision method for determining the direction with a $0.138^{\circ}$ step yielded the effect of increasing gamma-quantum scattering over a copper-lead surface [4,5].

A review of scientific-and-technical literature has established the following precise instruments for determining the gamma source direction. Thus, [6] suggests determining the gamma source direction by using a panoramic detector with a coding collimator rotating through $360^{\circ}$ with a $24^{\circ}$ step. In this case, two-layer neutral net methods were used when the measurements were processed. Similar devices are instruments with a coded aperture [7] and a surroundview gamma-scanner with a coding mask, which have an angular resolution of about a hundredth of a degree [8]. These devices employ the method for visualizing a gamma-source by its spectrum by using coded apertures [9]. An identical instrument is a surround-view gamma-scanner with an angle resolution of $0.29^{\circ}$ [10]. A drawback of these devices is that the gamma-source direction can be found only with continuous rotation of the coding collimator. This hinders their application in certain areas, for instance, to control the gamma-radiation source (GRS) direction during its steady displacement jointly with the receiver to analyse the object of investigation.

Besides, it has been found [11] that detector displacement in the absorber cavity enables expanding the range of angles for finding the GRS direction.

Objective of the paper: establish the possibility of increasing the resolving power to determine the point gamma-source direction in the precision method, and find the optimal position of the detector in the asymmetric absorber.

\section{Presentation of basic material}

The precision method [12] uses an asymmetric absorber, an absorber shaped as a

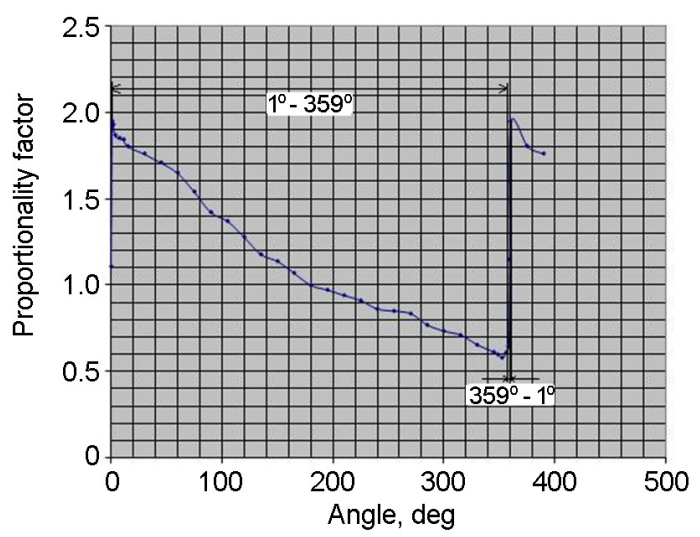

Fig. 1. Proportionality coefficient vs. angle in the asymmetric absorber plane. 


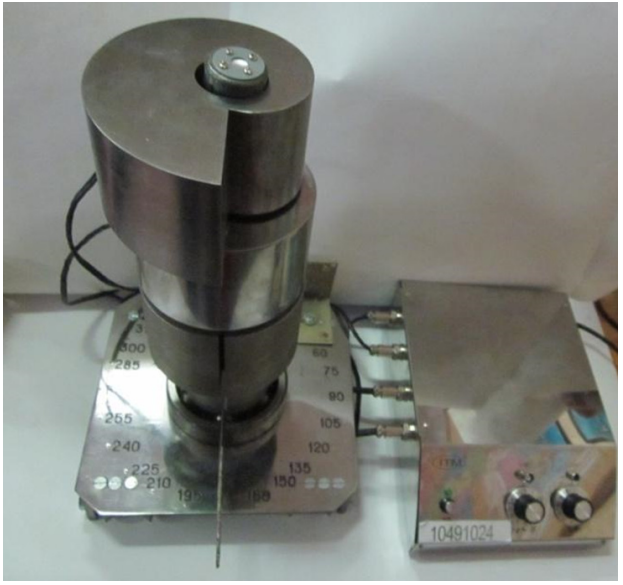

Fig. 2. Device for determining the point GRS direction with an asymmetric absorber, an absorber shaped as a coaxial cylinder, a sector absorber, and an analyser of gamma-radiation impulses.

coaxial cylinder and a sector absorber whose thickness is equal to that of the coaxial one. The sector absorber is used for initial measurement of the point GRS direction. The absorbers are fixed rigidly one above the other (Fig. 2).

Next, the point GRS direction is found precisely. To achieve this, the entire device described above is rotated over the minimal and maximum thickness of the asymmetric absorber to an angle specified a priori as the GRS direction. After device rotation, the amount of registered gamma-quanta passing through the sector absorber thickness decreases. This direction is determined by the equal count rate in the detectors located behind the sector absorber and in the coaxial cylinder. Thereat, the asymmetric absorber boundary was arranged at $4^{\circ}$ to the maximum thickness. Next, it was rotated successively to $5^{\circ}$ with $0.138^{\circ}$ steps toward the minimal thickness (Fig. 3a) [4]. During such rotation, the count rate grows pro rata to detector opening from behind maximum absorber thickness. When the boundary is in the GRS direction, corresponding to $0^{\circ}$, the gamma-quanta count rate is maximal and the total absorption peak is restored (Fig. 4) [4]. Note that the total absorption peak drops when gamma-quanta pass through the absorber thickness [13].

Fig. 4 demonstrates that the count rate increases with gradual opening of the detector from behind the absorber. The optimal position of the detector relative to the asymmetric absorber boundary was investigated. For this purpose, the detector was

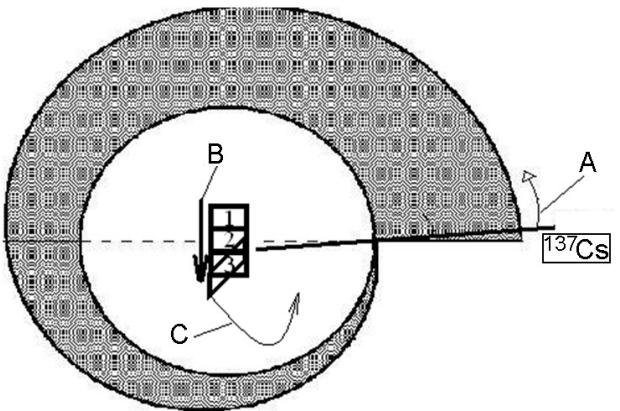

Fig. 3. Asymmetric detector with an absorber: A - position of asymmetric absorber boundary toward the GRS where the arrow shows the direction of rotation of the asymmetric absorber; B - detector position in the asymmetric absorber to determine its optimal position where the arrow and figures 1 (on the maximum thickness side), 2 (on the boundary), 3 (on the minimal thickness side) show the detector position in the experiments; C - detector position in the asymmetric absorber when detecting increasing gamma-radiation scattering over a copperlead surface.

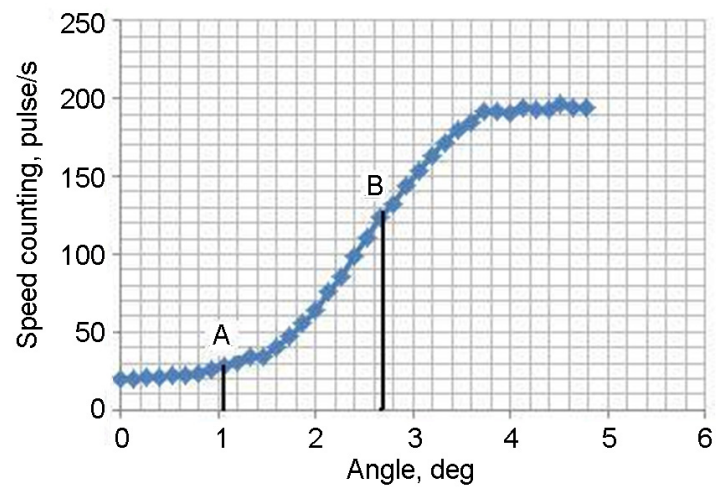

Fig. 4. Count rate vs. angle in the experiment for precision determination of the GRS direction with a $0.138^{\circ}$ step. The maximum count rate corresponds to the direction being determined. Interval $\mathrm{A}-\mathrm{B}$ corresponds to a range of angles where the total absorption peak area decreases.

positioned on the maximum thickness side of the asymmetric absorber; afterwards, on the boundary, and finally, on the minimum thickness side (Fig. 3b).

For the experiment, a ${ }^{137} \mathrm{Cs}$ GRS with an activity of $1.28 \cdot 10^{11} \mathrm{~Bq}$ was used. The distance to the GRS was $1 \mathrm{~m}$. The asymmetric steel absorber 3 was made using an electric spark discharge machine. Its dimensions were as follows: maximum thickness $60 \mathrm{~mm}$, height $80 \mathrm{~mm}$ and internal diameter $40 \mathrm{~mm}$. In its centre was positioned a 


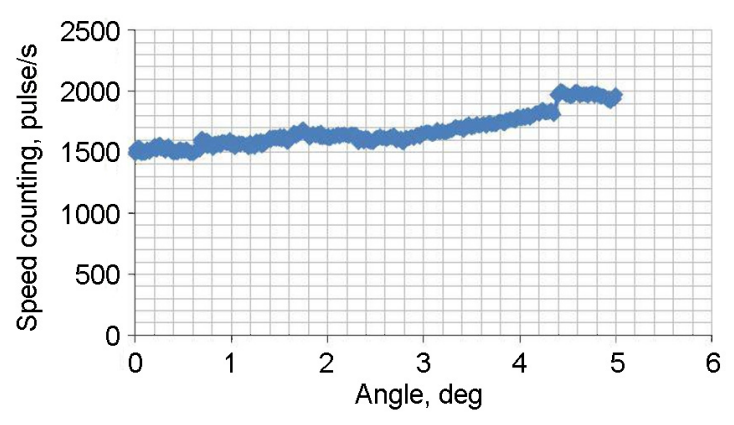

Fig. 5. Count rate vs. GRS angle with the detector positioned on the side of maximum asymmetric absorber thickness.

detector $20 \mathrm{~mm}$ long and with a $10 \mathrm{~mm}$ diameter. The telluride-cadmium detector dimensions were $4 \times 4 \times 2 \mathrm{~mm}^{3}$. The asymmetric absorber was rotated within a range of angles $356^{\circ}-1^{\circ}$ with a $0.0138^{\circ}$ step. This increased the resolving power by a factor of 10 as compared to the previous experiment [4]. At each step, the detector registered no less than 10,000 photons. First, the detector was positioned beyond the boundary of the maximum and minimum absorber thickness on the maximum thickness side (Fig. 1 in Fig. 3 (B). The detector plane was a continuation of this boundary, and the end surface was positioned orthogonally to the force of gravity vector and the absorber maximum thickness. Fig. 5 shows the count rate measurement results and the appropriate angles. The dependence obtained (Fig. 5) shows that, within the given range of angles, the detector does not open completely due to the absorber because the count rate changes merely by a factor of 1.3. Next, the detector was shifted with the middle of its end surface to the maximum and minimum thickness boundary (Fig. 2 in Fig. 3b). Conducting a similar experiment with a $0.0138^{\circ}$ step yielded the count rate vs. GRS angle dependence shown in Fig. 6. The dependence (Fig. 6) shows that, within the specified range of angles, the detector opens from behind the absorber, though it is unknown by how much. This can be attributed to the absence of an upper boundary with a constant count rate. The count rate in this case changes by a factor of 2.1. To cover the upper and lower boundary with a constant rate, the detector was shifted to the minimum absorber thickness side (Fig, 3 in Fig. 3 (B). In this case, the detector end surface was orthogonal to the gammaquanta beam direction parallel to the boundary surface and the force of gravity vector. The flat surface of the detector was the

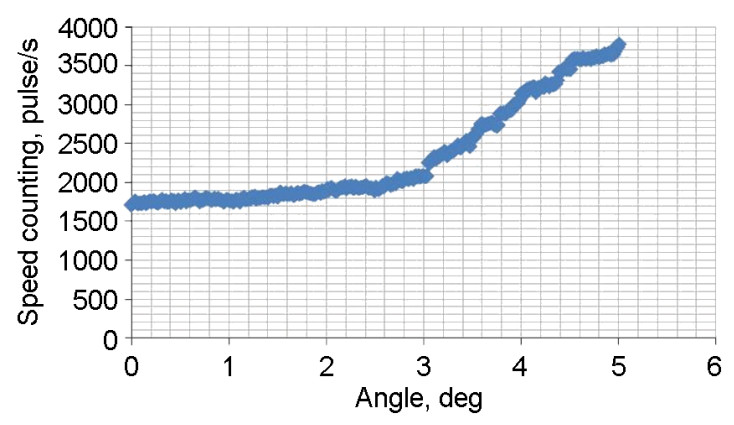

Fig. 6. Count rate vs. GRS angle with the detector positioned on the asymmetric absorber boundary.

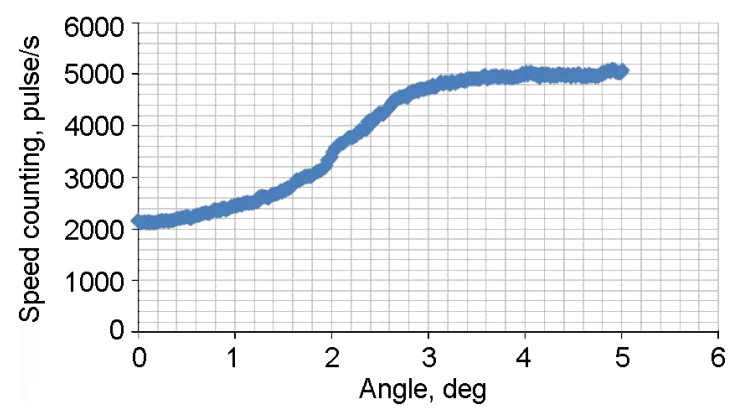

Fig. 7. Count rate vs. GRS angle with the detector positioned on the minimum asymmetric absorber thickness side.

continuation of a conventional line drawn in the plane of maximum asymmetric absorber thickness. The experiment in gradual rotation of the asymmetric absorber from maximum to minimum thickness within the range of angles $356^{\circ}-1^{\circ}$ and a $0.0138^{\circ}$ step yielded the count rate vs. GRS angle dependence (Fig. 7). The dependence obtained (Fig. 7) shows that, within the specified range of angles, the detector opens completely from behind the absorber because a lower and upper boundary with a constant count rate is in place. The count rate in this case changes by a factor of 2.4 .

As Fig. 8 shows, a bigger absorber thickness gradient and a respective count rate change was seen in the experiment using a lead filler in an "empty" asymmetric absorber. The "empty" asymmetric absorber was made of a flat copper bar $0.1 \mathrm{~mm}$ thick, with a maximum boundary thickness of $45 \mathrm{~mm}$, a $40 \mathrm{~mm}$ height and a $70 \mathrm{~mm}$ internal diameter. In the centre of the absorber was a detector with a $20 \mathrm{~mm}$ length and a $10 \mathrm{~mm}$ diameter. The dimensions of the telluride-cadmium detector were $4 \times 4 \times 2 \mathrm{~mm}^{3}$ [14]. The "empty" asymmetric absorber was filled with $3.75 \mathrm{~mm}$ diameter lead beads. 


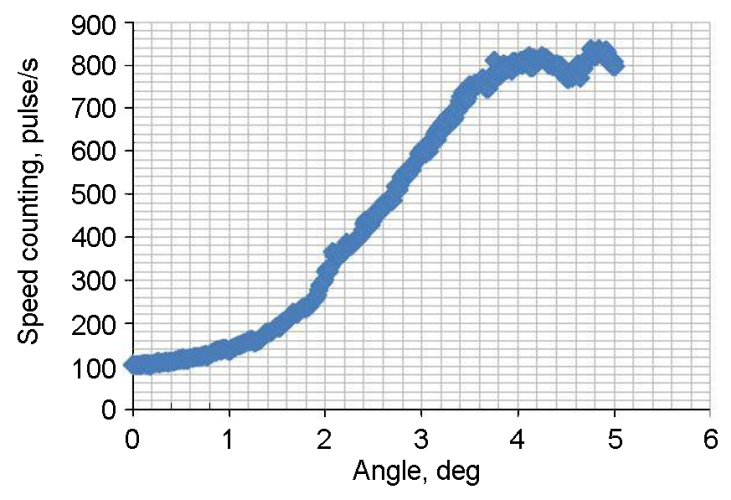

Fig. 8. Count rate vs. GRS angle with the detector positioned on the minimum asymmetric absorber thickness side, with a lead filler being used.

A comparison of Figs. 8 and 7 for the lead absorber shows a count rate change higher by a factor of 3.2, though the absorber thickness gradient for steel is higher by a factor of 1.3 .

Besides, the experimental data [4] were used to conduct further experimental research in the precision method with a $0.138^{\circ}$ step. In this case, lead filler, which filled the "empty" asymmetric absorber and a spectrometric telluride-cadmium detector with dimensions of $5 \times 5 \times 2 \mathrm{~mm}^{3}$ were used. In these experiments, the detector was rotated about its axis from $0^{\circ}$ through $45^{\circ}$ with a $15^{\circ}$ step. At each step, the detector position was fixed and the asymmetric absorber was rotated as mentioned above with a $0.138^{\circ}$ step. The count rate increased and a total absorption peak drop was observed according to [4]. It was found that the effect of gamma-radiation scattering over a copper-lead surface is observed when the telluride-cadmium detector is positioned with its rectangular side edges of $5 \times 2 \mathrm{~mm}^{2}$ and $5 \times 5 \mathrm{~mm}$ parallel to the copper-lead surface (Fig. 3).

\section{Conclusions}

Experiments have established that, in the precision method for determining the point GRS direction with a decreasing step of rotation of an asymmetric absorber, the accuracy of determining the direction can be increased. This enables directing reliably the asymmetric absorber boundary to the GRS. Besides, the optimal position of the detector was found. It should be positioned immediately beyond the maximum and minimum thickness boundary on the side of the minimum asymmetric absorber thickness. This position helps determine the minimum and maximum count rate. To detect the scattering effect of gamma-radiation when it passes over a copper-lead surface, the telluride-cadmium detector should be positioned optimally so that the diagonal of the rectangular parallelepiped would be parallel to the copper-lead surface.

\section{References}

1. Patent UA 85911 (2013).

2. Z.V.Bilyk, A.N.Grigoryev, A.V.Sakun, V.V.Marushchenko, in: Proc. XXI Intern. Nauk. Practical. Conf., Kharkiv, NTU "KPI" (2013), p. 138 [in Ukraine].

3. A.N.Grigoryev, Z.V.Bilyk, A.V.Sakun, V.V.Marushchenko, Visnyk NTU "KPI", 41, 111 (2012).

4. A.N.Grigoryev, Z.V.Bilyk, Yu.V.Litvinov et al., Nucl.Rad.Safety J., 3, 33 (2014).

5. Z.V.Bilyk, A.N.Grigoryev, Yu.V.Litvinov et al., in: Proc. of Ukr. Nauk. Practical. Conf., Odessa Military Academy (2014), p.165

6. Ning Win, Author's Abstract Dis. cand. fiz.mat. sciences, Moscow, 2007.

7. A.K.Shevchenko, Bull. KSPU, 4, 131 (2009).

8. V.Yu.Plakhotnik, E.G.Yaroshchuk, Bulletin $K S P U$, 5, 32 (2008).

9. E.G.Yaroshchuk, Bull. SevNTU, Phys. Math. Coll. Sci. Works, 99, 100, (2009).

10. P.Yu.Voilov, A.V.Kochergin, Proceedings, Technological Safety, 151, 163 (2011).

11. T.V.Malykhina, Author's Abstract Dis. cand. fiz.-mat. sciences, Sumy (2015).

12. A.N.Grigoryev, Z.V.Bilyk, A.V.Sakun, V.V.Marushchenko, Milit.Techn.Collect., $\mathbf{2}$, 45, (2012).

13. A.N.Grigoryev, Z.V.Bilyk, Yu.V.Litvinov et al., Visnyk NTU "KPI", 19, 1128 (2016).

14. A.N.Grigoryev, N.E.Polyansky, A.G.Kareev, T.A.Zhadan, Bull. Kharkov State Univ., 544, (2002). 